Ernest O. Okpako*

University of Ibadan, Nigeria

\title{
COMPARATIVE INVESTIGATION OF JOB MOTIVATION, PERCEIVED JOB STRESS AND JOB SATISFACTION ON TEACHERS EFFICACY AMONG PUBLIC AND PRIVATE SECONDARY SCHOOL TEACHERS IN EKITI STATE, NIGERIA
}

\begin{abstract}
The study examines the comparative investigation of job motivation, perceived job stress and job satisfaction on teacher's efficacy among public and private secondary school teachers in Ekiti State, Nigeria. The study adopted a descriptive design of correlational type. A Sample of two hundred hundred fifty public and private secondary school teachers were selected using a multi-stage sampling technique. Four scales were used to collect information. Eight research questions were raised and answered in the study. Data collected were analyzed using T-test and Multiple regression analysis. Results indicated that there was a significant difference in the teaching efficacy of public and private secondary school teachers; $\mathrm{t}(248)=-3.206, \mathrm{p}<.05$, there was also a significant difference in the job motivation of public and private secondary school teachers; $\mathrm{t}(248)=-2.159, \mathrm{p}<.05$, a significant difference also was observed in the perceived stress of public and private secondary school teachers; $t(248)=$ $-3.648, \mathrm{p}<.05$ and a significant difference in the job satisfaction of public and private secondary school teachers was also observed; $\mathrm{t}(248)=-2.742, \mathrm{p}>.05$. The Regression analysis revealed that there was a joint effect of the independent variables (job motivation, perceived stress and job satisfaction) on public school teachers' efficacy $(\mathrm{R}=.598, \mathrm{P}<.05) .34 .3 \%$ of the variance was accounted for by the predictor variables when taken together. The significance of the composite contribution was tested at $(\mathrm{P}<.05)$. Furthermore, there was also a joint effect of the independent variables (job motivation, perceived stress and job satisfaction) on private school teachers' efficacy $(\mathrm{R}=.641, \mathrm{P}<.05) .39 .4 \%$ of the variance was accounted for by the predictor variables when taken together. The significance of the composite contribution was tested at $(\mathrm{P}<.05)$. It is recommended from the findings of the study that the welfare of teachers who are the engine room of secondary education is very critical to their efficacy most notably in the private secondary school section. Also, Government, employers and stakeholders in the secondary education must ensure the wellness of teachers
\end{abstract}

\footnotetext{
*ernest.kelvin26@gmail.com
} 
Okpako, E.: Comparative Investigation of Job Motivation, Perceived Job Stress...

ЗБОРНИК РАДОВА • ГОД. 23 • БР. 22 • ДЕЦЕМБАР 2020 • 25-42

in order to facilitate the learning process towards good teaching, self-development of teachers, students and nation at large.

Keyword: Teacher Efficacy, Job motivation, Job Satisfaction, Perceived Stress, Teachers.

\section{BACKGROUND OF THE STUDY}

Globally, education remains the engine room of development in all sectors. These underscores, the importance of teachers, especially at the secondary school level, which is a feeding sub-sector of education at the tertiary level. The primary goal of any school is the attainment of academic excellence by the students though there may be other peripheral objectives. The extent to which this goal is achieved depends principally on the workforce most especially the teaching personnel. Teachers like other employees in an organization play a crucial role in the actualization of the school goals and objectives as well as in the implementation of educational policies and principles. Teaching efficacy is highly related to students' outcome as the end-product of education. Their perceived strength and effectiveness is reflected in the standard of education and performance of students in internal and external examinations hence; they constitute the oil that lubricates the factors of academic achievement and educational enterprise as a whole. When teaching efficacy decreases, it will adversely affect students' outcomes.

Education is to bring out abilities and potentials in individual and also to nurture what has been brought out. It is the building stones of any scientifically and technological advancement, which lays a good foundation that would facilitate the development of human and capital resources that will bring about a sane society. However, education has been found wanting in these regards due to the reduced efficacy of teachers who are the major key player in transforming educational objectives into reality. Teachers are arguably the most critical professional in nation's development (Bishay, 2006) consequently; their efficacy at work is paramount to the educational development of the society. An educational system is usually considered to be the fundamental principle of a developing country. Effective teachers are vital for the accomplishment of an educational system. A high demanding educational system has made the teaching profession extremely challenging, as high performance is expected from teachers. Teachers who are satisfied with their jobs usually have a high degree of professional capabilities and feel that they could manage, organise and perform specific tasks and behaviour, even in case of failure (Gkolia, Belias, Koustelios, 2014).

Teachers Efficacy is defined as the extent to which a teacher believes he or she can affect student performance; teacher efficacy has been related to individual differences in teachers' feedback toward and expectations for students (Gibson \& Dembo, 1984) and to teachers' control orientations (Woolfolk \& Hoy, 1990). 
Moreover, teacher efficacy has been positively associated with academic achievement in students (Anderson, Greene, Loewen, 1988; Ashton \& Webb, 1986). According to Bandura (1993), links between efficacy and achievement might be explained by the learning environments teachers create for their students. For instance, teacher efficacy could play a role in the goal's teachers set for themselves and their students, how motivated teachers are to create a positive learning environment, how much effort they expend in teaching students, and how they react when faced with difficult situations. Each of these factors could lead to positive or negative instructional practices, which could then impact student achievement.

The first factor that will be considered in this research is perceived job stress, and according to Mason (1975), stress was approached in four different ways, Stimulus or external force acting on the organism, Response or changes in the physiological functions, External force and resistance opposed to it and Comprehensive phenomenon encompassing all these. The teachers serve one of the most stressful professions. Stress is costly to the individual as well as to the institution where he/she works (Cooper \& Marshal, 1978). Borg (1990) conceptualizes teacher stress as negative and potentially harmful to teachers' health and effectiveness. In a survey assessing the stress levels of various jobs by the Health and Safety Executive, teaching came out top. The report found that $41.5 \%$ of teachers reported themselves 'highly stressed', while 58.5\% came into a 'low stress' category, while $36 \%$ of teachers felt the effects of stress all or most of the time. This is indeed an alarming state and visibly also the biggest reason for school teacher's poor performance in their duties and quitting at a very high percentage or seeking professional help to fight back stress. Stress has become increasingly common in the teaching profession primarily because of increased complexities and increased economic pressure on individuals. A significant source of distress among teachers is the result of a failure of the school to meet the social needs and jobs demands of the teachers. According to Schwarzer and Greenglass, (1999) in their study of the relationship between occupational stress and teacher efficacy, they asserted that the construct of teacher-efficacy suggests a protective effect when coping with adversity. They stated further that an optimistic belief in one's competence to deal with daily challenges enhances the motivation to engage in constructive ways of coping. Thus, self-efficacious teachers would perceive the physical demands of daily teaching as being less threatening than those teachers that harbor self-doubts about their professional performance. Successful adaptation to stressful demands, in turn, would prevent the emergence of occupational stress and rebuild teaching efficacy (Caprara et al., 2003; Schmitz \& Schwarzer, 2002; Schwarzer \& Greenglass, 1999; Skaalvik \& Skaalvik, 2007).

Motivation is also another factor of interest in this study; motivation and performance are critical factors in terms of organizational success and achievements. Motivation plays a vital role in the organization as it tends to increase the productivity of employees and to prompt the organizational goals to achieve in an efficient way (Jehangir, 2015). Motivation also takes part in an important role for 
teachers as it helps to achieve the target efficiently. Teacher motivation is essential because it improves the skills and knowledge of teachers directly influential on student's achievement (Mustafa \& Othman, 2010). If in school, teachers are not adequately motivated, they tend to be less committed to effective teaching. Looney (2003) conducted a study on teacher motivation and teaching efficacy. A total of 229 teachers from nine high schools in a middle-class school district participated in the study. Results from hierarchical regression analyses indicate that: motivation was a significant and positive predictor of teachers' overall efficacy and efficacy for classroom management, instructional practices, and student engagement. Hoy and Woolfolk (1993) explored the relationship between organizational characteristics which are principal influence, motivation and schools' emphasis and teacher efficacy. Mainly, they sampled 179 teachers from 37 elementary schools and assessed schools' ability to cope with outside pressures, principals' ability to influence the actions of higher-level administrators, principals' considerate behavior and genuine concern for teachers (similar to Newmann et al.'s, 1989 assessment of administrative responsiveness), schools' supplies of adequate resources, and the extent to which schools strive for academic excellence. Teacher efficacy was assessed using an adapted version of Gibson and Dembo's (1984) Teacher Efficacy Scale. Findings showed that principal influence, motivation and schools' emphasis on academic excellence were both related to teachers' efficacy. In contrast, principals' polite behavior was not related to efficacy, contradicting findings from Newmann et al.'s (1989) investigation.

The last factor that will also be considered is job satisfaction, and it is also a predicting factor for teaching efficacy. Babita and Gurmit (2014) point out that those teachers who are not satisfied with their job might be less committed hence, perform below their capabilities and that the teaching profession is facing problems related to teachers' job satisfaction. Parasuraman, Uli and Abdalla (2009) agree that the general perception is that teachers in the government schools are dissatisfied with their profession. Ogochi (2014)'s study in Transmara, Kenya also agrees that lack of job satisfaction has led to low performance in national examinations and that people cannot develop their full potential when their esteem is low and not appreciated. A study in Ireland by Reilly and Eithne, (2012) revealed that teachers who are dissatisfied with their work exhibit lower commitment and therefore, they are ultimately at a higher risk of leaving their profession. Salim, Nasir, Arip and Mustafa, (2012) argued that job satisfaction enhances organizational commitment, organizational citizenship behavior and employee wellbeing. Teachers who are satisfied with jobs usually have a high degree of professional competence and teaching skills and feel secured about classroom management. Researches have shown that teachers with high teaching-efficacy create new powerful incentives for learning to the students, consequently improving their marks. Also, they devote themselves to their work and desire to remain in their position for as long as possible (Coladarci, 1992; Reyes \& Shin, 1995). The relation between teaching efficacy and job satisfaction is essential. Several studies have proven that teachers who are more 
enthusiastic and satisfied with their job tend to be characterized by high teaching efficacy (Caprara, Barbaranelli, Borgogni, Steca, 2003; Caprara, Barbaranelli, Steca \& Malone, 2006). A leader-principal reinforces the power of self-efficacy. Teachers who feel comfortable with their working environment and are personally supported by the administration tend to have higher self-efficacy (Leithwood \& Jantzi, 2005; Lewandowski, 2005). Hipp (1997) in a study confirmed that when teachers are provided with informative feedback about their performance and when these performances are satisfactory to them, it is very likely to enhance the latter's capacity beliefs, teaching efficacy, effort, which all lead to job commitment and academic success of students.

\section{Research questions}

1. What is the difference in the teaching efficacy of public and private secondary school teachers?

2. What is the difference in the job motivation of public and private secondary school teachers?

3. What is the difference in the job satisfaction of public and private secondary school teachers?

4. What is the difference in the stress of public and private secondary school teachers?

5. What is the joint effect of job motivation, job satisfaction and stress on public secondary school teacher's efficacy?

6. What is the relative effect of job motivation, job satisfaction and stress on public secondary school teacher's efficacy?

7. What is the joint effect of job motivation, job satisfaction and stress on private secondary school teacher's efficacy?

8. What is the relative effect of job motivation, job satisfaction and stress on private secondary school teacher's efficacy?

\section{METHODOLOGY}

\section{Research Design}

The study adopted a descriptive research design of correlational type. This design is appropriate because the variable was not manipulated but described as they naturally occur among the respondents. 
Okpako, E.: Comparative Investigation of Job Motivation, Perceived Job Stress...

ЗБОРНИК РАДОВА • ГОД. 23 • БР. 22 • ДЕЦЕМБАР 2020 • 25-42

\section{Sample and Sampling Procedure}

The sample for this study comprises of Two Hundred and Fifty (250) secondary school teachers in Ekiti State. However, participants were selected from five (5) major local government areas in Ekiti state (Ado Ekiti, Ikere, Oye, Efon and Gbonyin) through the Simple Random Sampling method, and the method was also adopted in selecting one school from each of the selected local government areas. Also, the Simple Random Sampling which was found suitable for the study, was used to select Fifty (50) respondents from each selected school of the selected Local Government Areas.

\section{RESEARCH INSTRUMENT}

Teaching Efficacy Scale: The Teaching-Efficacy scale developed by Albert Bandura (1998) was adopted to measure the degree of the teacher self-efficacy. The teacher efficacy scale (TES) consists of seven (7) factors: efficacy to influence decision making, efficacy to influence school resources, instructional self-efficacy, disciplinary self-efficacy, efficacy to enlist parental involvement, efficacy to enlist community involvement, efficacy to create a positive school climate with a total of thirty (10) items on a five-point response format ranging from Nothing $=1$ to A great deal $=5$. A higher score indicates a higher level of teacher efficacy. Sample items are: "how much can you influence the decisions that are made in the school", and "How much can you express your views freely on important school matters".

Job motivation scale: The Motivation Scale developed by Deci and Ryan (2000) was adopted to measure teachers job motivation. Sample items include: 'Because this is the type of work I chose to do to attain a certain lifestyle' and 'I ask myself this question, I do not seem to be able to manage the important tasks related to this work'. The scale contains ten items on five-point Likert response format ranging from $\mathrm{SD}=$ Strongly Disagree to $\mathrm{SA}=$ Strongly Agree

Job satisfaction scale: The Teacher Job Satisfaction Scale (TJSS) developed by Liu, Borg, and Spector (2004) was used to measure teachers' job satisfaction. The scale is used to measure the satisfaction level of teachers as regards their teaching engagement. The TJSS-9 items are composed of three factors namely: satisfaction with co-workers ( 3 items), satisfaction with parents (3 items) and satisfaction with students' behaviors (3 items) with nine items in total, and was adapted on a five-point response format ranging from HS = Highly Satisfied to HD $=$ Highly Dissatisfied. Sample items include: 'The quality of your relations with co-workers' and 'your overall satisfaction with your co-workers'.

Job stress scale: Stress Scale developed by Cohen (1994) was adopted to measure respondents job stress. The scale is used to measure perceived stress of employees at a work role. The Perceived Stress Scale contains 14 items to which 
employees are allowed to provide answers to the item statements on a five-point Likert scale: Strongly Agree (SA), Agree (A), Undecided (U), Disagree (D), and Strongly Disagree (SD).

\section{METHODS OF DATA ANALYSIS}

The data collected were analyzed using SPSS version 25, demographic variables were analyzed using mean and standard deviation, T-test and Multiple regression analysis were used to analyze the research questions, and all the research questions were tested at .05 level of significance.

\section{RESULTS}

Research question 1: What is the significant difference in the Teaching efficacy of public and private secondary school teachers.

The research question was tested using t-test.

Table 1. T-test Summary Showing Difference in Teaching efficacy of public and private secondary school teachers

\begin{tabular}{|c|c|c|c|c|c|c|c|c|}
\hline & & $\mathbf{N}$ & Mean & St. Dv & Df & $\mathbf{T}$ & Sig & $\mathbf{P}$ \\
\hline \multirow{2}{*}{$\begin{array}{l}\text { Teaching } \\
\text { efficacy }\end{array}$} & Public & 143 & 25.5887 & 7.95805 & \multirow[t]{2}{*}{248} & \multirow[t]{2}{*}{-3.206} & \multirow[t]{2}{*}{.002} & \multirow[t]{2}{*}{$<.05$} \\
\hline & Private & 107 & 28.7143 & 7.15776 & & & & \\
\hline
\end{tabular}

Table 1 revealed that there was a significant difference in the teaching efficacy of public and private secondary school teachers; $\mathrm{t}(248)=-3.206, \mathrm{p}<.05, \mathrm{y}^{2}=$ .4129. The table further reveals revealed that private secondary school teachers teaching efficacy is more than their counterpart in the public secondary school.

Research question 2: What is the significant difference in the job motivation of public and private secondary school teachers.

The research question was tested using t-test. 
Okpako, E.: Comparative Investigation of Job Motivation, Perceived Job Stress... ЗБОРНИК РАДОВА • ГОД. 23 • БР. 22 • ДЕЦЕМБАР 2020 • 25-42

Table 2. T-test Summary Showing Difference in job motivation of public and private secondary school teachers

\begin{tabular}{llccccccc}
\hline & & N & Mean & St. Dv & Df & T & Sig & P \\
\hline \multirow{2}{*}{ Motivation } & Public & 143 & 22.3613 & 6.80817 & 248 & -2.159 & .032 & $<.05$ \\
& Private & 107 & 24.4676 & 8.61166 & & & & \\
\hline
\end{tabular}

Table 2 revealed that there was a significant difference in the job motivation of public and private secondary school teachers; $\mathrm{t}(248)=-2.159, \mathrm{p}<.05, \mathrm{y}^{2}=.2713$. The table further reveals revealed that private secondary school teachers had better motivation to do their work than their counterpart in the public secondary school.

Research question 3: What is the significant difference in the perceived stress of public and private secondary school teachers.

The research question was tested using t-test.

Table 3. T-test Summary Showing Difference in perceived stress of public and private secondary school teachers

\begin{tabular}{lcccccccc}
\hline & & N & Mean & St. Dv & Df & T & Sig & P \\
\hline \multirow{2}{*}{ Stress } & Public & 143 & 25.3070 & 7.41669 & 248 & -3.648 & .000 & $<.05$ \\
\cline { 2 - 9 } & Private & 107 & 28.7143 & 7.15776 & & & & \\
\hline
\end{tabular}

Table 3 revealed that there was a significant difference in the perceived stress of public and private secondary school teachers; $\mathrm{t}(248)=-3.648, \mathrm{p}<.05, \mathrm{y}^{2}=.4674$. The table further reveals revealed that private secondary school teachers experience stress more than their counterpart in the public secondary school.

Research question 4: What is the significant difference in the job satisfaction of public and private secondary school teachers.

The research question was tested using t-test.

Table 4. T-test Summary Showing Difference in job satisfaction of public and private secondary school teachers

\begin{tabular}{llccccccc}
\hline & & N & Mean & St. Dv & Df & T & Sig & P \\
\hline \multirow{2}{*}{ Satisfaction } & Public & 143 & 25.9595 & 8.71313 & 248 & -2.742 & .007 & $<.05$ \\
& Private & 107 & 28.7143 & 7.15776 & & & & \\
\hline
\end{tabular}

Table 4 revealed that there was a significant difference in the job satisfaction of public and private secondary school teachers; $\mathrm{t}(248)=-2.742, \mathrm{p}>.05, \mathrm{y}^{2}=.3912$. 
Okpako, E.: Comparative Investigation of Job Motivation, Perceived Job Stress... ЗБОРНИК РАДОВА • ГОД. 23 • БР. 22 • ДЕЦЕМБАР 2020 • 25-42

The table further reveals revealed that private secondary school teachers experience stress more than their counterpart in the public secondary school.

Research Question Five: What is the joint contribution of job motivation, job stress and job satisfaction on public school teacher's efficacy?

Table 5. Regression summary showing the joint effect of the variables on public school teachers' efficacy

\begin{tabular}{|c|c|c|c|c|c|}
\hline \multicolumn{6}{|c|}{$\begin{array}{l}\mathrm{R}=.598 \\
\mathrm{R}^{2}=.357 \\
\mathrm{R}^{2} \text { (adjusted) }=.343 \\
\text { Standard error of estimate }=8.03630\end{array}$} \\
\hline \multicolumn{6}{|c|}{ Analysis of variance } \\
\hline & $\begin{array}{l}\text { Sum of square } \\
\text { (SS) }\end{array}$ & $\mathrm{DF}$ & $\begin{array}{l}\text { Mean } \\
\text { square }\end{array}$ & $\mathrm{F}$ & sig \\
\hline Regression & 4986.045 & 3 & 1662.015 & & \\
\hline Residual & 8976.904 & 139 & 64.582 & 25.735 & .000 \\
\hline Total & 13962.949 & 142 & & & \\
\hline
\end{tabular}

Table 5 shows that the joint effect of the independent variables (job motivation, job stress and job satisfaction) on public school teachers' efficacy. The table also shows that $\mathrm{R}=.598$ and a adjusted $\mathrm{R}^{2}$ of .343 . This means that $34.3 \%$ of the variance was accounted for by the predictor variables when taken together. The significance of the composite contribution was tested at $\mathrm{P}<.05$. The table also shows that the analysis of variance (ANOVA) for the regression yielded a F-ratio of 25.735 (significant at .05 level). This implies that the joint contribution of the independent variables to the dependent variable was significant and that other variables not included in this model may have accounted for the remaining variance.

Research Question Six: What is the relative effect of independent variables (job motivation, job stress and job satisfaction) on public secondary school teachers efficacy? 
Okpako, E.: Comparative Investigation of Job Motivation, Perceived Job Stress... ЗБОРНИК РАДОВА • ГОД. 23 • БР. 22 • ДЕЦЕМБАР $2020 \bullet 25-42$

Table 6. Relative Contribution of Independent Variables to the Prediction of Public-school Teachers Efficacy

\begin{tabular}{|c|c|c|c|c|c|}
\hline \multirow[t]{2}{*}{ Model } & \multicolumn{2}{|c|}{$\begin{array}{l}\text { Unstandardized } \\
\text { Coefficients }\end{array}$} & $\begin{array}{c}\text { Standardized } \\
\text { Coefficients }\end{array}$ & \multirow[t]{2}{*}{$\mathrm{t}$} & \multirow[t]{2}{*}{ Sig. } \\
\hline & & Std. Error & Beta & & \\
\hline (Constant) & 2.527 & 3.560 & & -.710 & .479 \\
\hline Job Motivation & .395 & .082 & .332 & 4.839 & .000 \\
\hline Job Stress & .177 & .082 & .147 & 2.153 & .033 \\
\hline Job Satisfaction & .537 & .085 & .435 & 6.349 & .000 \\
\hline
\end{tabular}

The table above 6 shows how each of the independent variables made significant contribution to the prediction of teachers efficacy among public secondary school teachers. As obtained, job satisfaction had the most significant contribution to the criterion (public school teachers efficacy), $($ Beta $=.435 ; \mathrm{t}=$ $6.349 ; \mathrm{P}<.05)$; then job motivation $($ Beta $=.332 ; \mathrm{t}=4.839 ; \mathrm{P}<.05)$; and job stress $($ Beta $=.147 ; \mathrm{t}=2.153 ; \mathrm{P}<0.05)$.

Research Question Seven: What is the joint contribution of job motivation, job stress and job satisfaction on private school teacher's efficacy?

Table 7. Regression summary showing the joint effect of the variables on public school teachers' efficacy

$$
\begin{aligned}
& \mathrm{R}=.641 \\
& \mathrm{R}^{2}=.411 \\
& \mathrm{R}^{2} \text { (adjusted) }=.394 \\
& \text { Standard error of estimate }=7.73694
\end{aligned}
$$

\begin{tabular}{lccccc}
\hline \multicolumn{5}{c}{ Analysis of variance } \\
\hline & $\begin{array}{c}\text { Sum of square } \\
(\mathrm{SS})\end{array}$ & DF & $\begin{array}{c}\text { Mean } \\
\text { square }\end{array}$ & F & sig \\
\hline Regression & 4305.386 & 3 & 1435.129 & & \\
Residual & 6165.601 & 103 & 59.860 & 23.975 & .000 \\
Total & 10470.987 & 106 & & & \\
\hline
\end{tabular}

Table 7 shows that the joint effect of the independent variables (job motivation, job stress and job satisfaction) on private school teachers' efficacy. The table also shows that $\mathrm{R}=.641$ and a adjusted $\mathrm{R}^{2}$ of .394 . This means that $39.4 \%$ of the variance was accounted for by the predictor variables when taken together. The significance of the composite contribution was tested at $\mathrm{P}<.05$. The table also shows that the analysis of variance (ANOVA) for the regression yielded a F-ratio of 23.975 (significant at .05 level). This implies that the joint contribution of the independent variables to the dependent variable was significant and that other variables not included in this model may have accounted for the remaining variance. 
Okpako, E.: Comparative Investigation of Job Motivation, Perceived Job Stress...

ЗБОРНИК РАДОВА • ГОД. 23 • БР. 22 • ДЕЦЕМБАР 2020 • 25-42

Research Question Eight: What is the relative effect of independent variables (job motivation, job stress and job satisfaction) on private school teachers efficacy?

\section{Table 8. Relative Contribution of Independent Variables to the Prediction of Private school Teachers Efficacy}

\begin{tabular}{lccccc}
\hline \multirow{2}{*}{ Model } & \multicolumn{2}{c}{$\begin{array}{c}\text { Unstandardized } \\
\text { Coefficients }\end{array}$} & $\begin{array}{c}\text { Standardized } \\
\text { Coefficients }\end{array}$ & \multirow{2}{*}{$\mathrm{t}$} & \multirow{2}{*}{ Sig. } \\
\cline { 2 - 4 } & $\mathrm{B}$ & Std. Error & Beta & & \\
\hline (Constant) & 3.906 & 2.890 & & 1.352 & .179 \\
Job Motivation & .114 & .126 & .097 & .908 & .366 \\
Job Stress & .582 & .143 & .478 & 4.060 & .000 \\
Job Satisfaction & .177 & .109 & .147 & 1.631 & .106 \\
\hline
\end{tabular}

The table above 8 shows how each of the independent variables made significant contribution to the prediction of teacher's efficacy among private secondary school teachers. As obtained, job stress had the most significant contribution to the criterion (private school teachers' efficacy), (Beta $=.478$; $\mathrm{t}=4.060 ; \mathrm{P}<.05)$. However, job satisfaction $($ Beta $=.147 ; \mathrm{t}=1.631 ; \mathrm{P}>.05)$ and job motivation (Beta $=.097 ; \mathrm{t}=.908 ; \mathrm{P}>.05$ ) did not independently predict teachers efficacy among private secondary school teachers.

\section{DISCUSSION OF FINDINGS}

The first research question examined the difference between the teaching efficacy of public and private secondary school teachers. The result shows that there was a difference in the teaching efficacy of public and private secondary school teachers. The results revealed that private secondary teachers had more teaching efficacy than public secondary school teachers. There are various reasons for this difference, including the different culture of public and private schools. The result supported the study carried out by Lin \& Garrel (2001) who suggested in their study that the notion of teacher efficacy may be culturally oriented and thus require careful examination when applied in diverse contexts and institutes of different nature, community and environment because the conception of workplace contribute very much to teachers efficacy beliefs.

The second research question also examined the difference in the job motivation of public and private secondary school teachers. Results indicated that private secondary school teachers showed higher job motivation than their public secondary school counterpart. The finding is in agreement with the finding of Lee, Bryk \& Smith (1993) who investigated the role of school administration which are motivation, training and teacher empowerment on teaching efficacy of teachers and 
often this is often not found in the public secondary school. The possible explanation for this finding is that motivation is a positive construct; employees are fun of positive self-evaluation and image whenever they are motivated and happy. In this sense, they often believe they can do better in their work role. Motivation itself can trigger motives to improve oneself in a working role in order to continue to experience further incentives which will further serve as motivation and job satisfaction.

The third research question also examined the difference in the perceived stress of public and private secondary school teachers. Results indicated that private secondary school teachers showed higher job stress or experience stress more than their public secondary school counterpart. This finding is in tandem with Alarcon et al. (2009), who found that the most active associations were observed for job-efficacy and occupational stress among workers of various professions. Similarly, Schwarzer \& Greenglass (1999) in their study of the relationship between occupational stress and teacher efficacy, found an association between the variables. They asserted that the construct of teacher-efficacy suggests a protective effect when coping with adversity and stress patterns in the working environment may also prompt progress by making an individual seek possible in ameliorating stressful conditions. In giving possible explanation for this study, a critical look at the private secondary school, it is worthy of note that teachers in the private school section are more stressed as a result of demands from the proprietor who monitors the teachers almost every time and demands from the parents who have paid much money in school fees hence, the teacher tend to satisfy all these demands by teaching much more better, giving assignments to the students always, regular monitoring of students performance, however, this can be hardly be found in the public secondary school section where almost all the teachers show lackadaisical attitudes towards teaching, some of them go to classes to beat, some of them are not regular in classes and some even leave the school to face some other business which leaves their primary work which is teaching suffering. One can assert that stress is a negative stimulus and may not become a source of strength in the working environment. Everyone in a situation of stress worried, a state of psychological deterioration may be activated leading such individual to malfunction in the working role. This reason might be said to be the cause of this finding.

The fourth research question also examined the difference in the job satisfaction of public and private secondary school teachers. Results indicated that private secondary school teachers are more satisfied than their public secondary school counterpart. This result corroborates the findings of Hipp (1997) who confirmed that when teachers are provided with informative feedback about their performance and when these performances are satisfactory to them, it is very likely to enhance the latter's capacity beliefs, teaching efficacy, effort, which all lead to job commitment and academic success of students which of course is often found in the private secondary school section and most private secondary school increase the pay and incentives of the teachers to reward their performance and when this is 
done, satisfaction increases. The non-job satisfaction of teachers in the public secondary school can be likened to their behaviours which is observable on how they handle their work, non-satisfaction makes some of them resumed to work very late or engage in other business apart from teaching.

The last three research question examined the joint effect of the factors on teaching efficacy of public and private secondary school teachers. The results showed that that job motivation, job satisfaction and perceived stress significantly and jointly influence teaching efficacy of public secondary school teachers while a significant and joint effect of the variables of study also predicted teaching efficacy among private secondary school teachers. This result is in line with the study of Schwarzer \& Greenglass (1999) who found an association between the variables. They asserted that the construct of teacher-efficacy suggests a protective effect when coping with adversity and stress patterns in the working environment may also prompt progress by making an individual seek possible in ameliorating stressful conditions. Also, Looney (2003) conducted a study on teacher motivation and teaching efficacy. The results from hierarchical regression analyses indicate that: motivation was a significant and positive predictor of teachers' overall efficacy and efficacy for classroom management, instructional practices, and student engagement. Also, as noted by Skaalvik and Skaalvik (2010) in their research among primary and middle school teachers in Norway, teacher' job satisfaction and teaching-efficacy had a strong positive relationship. The role of a teachers is therefore very crucial in the transformation of education in any society (Zvezdana \& Vesna, 2016). This assertion by the researcher is not far from the truth, the society is transformed if the teacher is available and the availability hinges on the result findings that it is important for teachers to be satisfied with the job, motivated to perform his or her role and the stress in the job should be within adaptability.

\section{CONCLUSION}

Teachers are the source of any nation's human resource. Primary education is given at the school level. It is imperative to note that the instructions students get exposed to at the secondary school level are very fundamental to their future career. The welfare of teachers who are the engine room of secondary education is very critical to their efficacy most notably in the public secondary school section. Government, employers and stakeholders in the secondary education must ensure the wellness of teachers in order to facilitate the learning process towards good teaching, self-development of teachers, students and nation at large. 


\section{Recommendations}

Based on the findings of this study, it is recommended that:

1. Government and employers of labor most especially in the teaching profession must endeavor to motivate their employees regularly. It is not a gainsaying that when employees/teachers are motivated and their conditions of service are satisfactory, they will undoubtedly endeavor to improve themselves towards effectiveness which will also, in turn, boost their efficacy.

2. Teacher's salary should be paid on time; they should have access to loans to develop themselves, certain fringes and benefits should be introduced into the teaching profession that will serve as a reward to hard work and effectiveness.

3. Government and employers of labor in the teaching profession should put all effort into making sure teachers physiological needs such as shelter, food, clothing and other basic needs are met periodically. When all these critical needs are met, teachers will be motivated to develop themselves and improve in their service delivery.

4. Stakeholders in the teaching profession must ensure that teachers are satisfied with their working condition in order to avoid chaos in the system. Even at the presence of adequate motivation, a sort of interview or survey should be administered to teachers periodically in order to assess their level of job satisfaction. When hiccups are noted through the survey, the further survey should be done on the lacking needs and aspirations of teachers that might have caused job dissatisfaction.

5. Developments and management challenges that may be causing issues among teachers and their students should be enquired at all time in order to stabilize the system and maintain a certain level of job satisfaction and proper functioning among the teachers towards role efficacy and effectiveness. 


\section{References}

Anderson, R. N., Greene, M. L. \& Loewen, P. S. (1988). Relationships among teachers' and students' thinking skills, sense of efficacy, and student achievement. Alberta Journal of Educational Research, 34, 148-165.

Ashton, P. T. \& Webb, R. B. (1986). Making a difference: Teachers' sense of efficacy and student achievement. New York: Longman.

Babita, A. \& Gurmit, S. (2014). Teacher effectiveness and self-confidence as a predictor of burnout among male Secondary School Edubeam. Multidisciplinary-Online Research Journal, 11(1), 2320-2341.

Bandura, A. (1998). Health promotion from the perspective of social cognitive theory. Psychology and Health, 13, 249-623.

Bishay, A. (2006). "Teacher motivation and job satisfaction: a study employing the experience sampling method". Journal of Undergraduate Sciences, 3(3), 147-155.

Borg, M. G. \& Riding, R. J. (1991) Occupational stress and satisfaction in teaching. British Educational Research Journal, 17, 263-281.

Caprara, G. V., Barbaranelli, C., Borgogni, L. \& Steca, P. (2003). Efficacy beliefs as determinants of teachers' job satisfaction. Journal of Educational Psychology, 95(4), 821-832.

Cohen, S. G. (1994). Designing self-managing work teams. In Advances in interdisciplinary studies of work teams, Vol. 1 series on self-managed work teams. Greenwich, CT: JAI Press.

Coladarci, T. (1992). Teachers' Sense of Efficacy and Commitment to Teaching. The Journal of Experimental Education, 60(4), 323-337.

Cooper, C. L. \& Dewe, P. J. (2008). Stress: A Brief History, Wiley.

Gibson, S. \& Dembo, M. H. (1984). Teacher efficacy: A construct validation. Journal of Educational Psychology, 76, 569-582.

Gkolia, A., Belias, D. \& Koustelios, A. (2014). Teacher's Job Satisfaction and Selfefficacy: A Review. European Scientific Journal, 10(22).

Hipp, K. A. (1997). Documenting the effects of transformational leadership behaviour on teacher efficacy. Paper presented at the annual meeting of the American Educational Research Association, Chicago.

Hoy, W. K. \& Woolfolk, A. E. (1990). The socialisation of student teachers. American Educational Research Journal, 27, 279-300.

Elezovic, Z. \& Minic, V. (2016). The Main Problems and the Role of Teachers in the Transformation of Education in Serbia. Mediterranean Journal of Social Sciences, $7(5)$. 
Jehangir, K., Glas, C. A. W. \& van den Berg, S. (2015). Exploring the relation between socioeconomic status and reading achievement in PISA 2009 through an intercepts-and-slopes-as-outcomes paradigm. International Journal of Educational Research, 71, 1-15.

Lee, V. E., Bryk, A.S. \& Smith, J. B. (1993). The organisation of effective secondary schools. Review of Research in Education, 19,171-267.

Leithwood, K. \& Jantzi, B. J. (2005). Transformational leadership. In B. Davies, Essentials of School Leadership (31-43). CA: Paul Chapman and Corwin, Thousand Oaks.

Lewandowski, K. L. (2005). A study of the relationship between teachers' self-efficacy and the impact of leadership and professional development. A Dissertation. Indiana: University of Pennsylvania.

Lin, H. \& Gorrel, J. (2001). Expletory analysis of pre-service teacher efficacy in Taiwan. Teaching and Teacher Education, 17, 623-635.

Liu, C., Borg, I. \& Spector, P. E. (2004). Measurement equivalence of the German Job Satisfaction Survey used in a multinational organization: implications of Schwartz's culture model. Journal of Applied Psychology, 89(6), 1070.

Looney, L. (2003). Understanding teachers' efficacy beliefs: The role of the professional community (Doctoral dissertation).

Mason, J. W. (1975). Emotion as reflected in patterns of endocrine integration. In L. Levi (ed.), Emotions: Their parameters and measurement (143-181). New York: Raven Press.

Mustafa, M. \& Othman, N. (2010). The effect of work motivation on teacher's work performance in Pekanbaru senior high schools, Riau Province, Indonesia. SOSIOHUMANIKA, 3(2), 259-272.

Newmann, F. M., Rutter, R.A. \& Smith, M.S. (1989). Organizational factors that affect school sense of efficacy, community and expectations. Sociology of Education, 62, 221-238.

Ogochi, G. (2014). Job Satisfaction and teacher Effectiveness in selected Secondary Schools in Trans Mara West District, Kenya. Journal of Education and Practice, 5(37), 125-142.

Parasuraman B., Uli, J. \& Abdullah, M. M. (2009). Job Satisfaction among Secondary School Teachers. Journal Kemanusiaan, 1(3), 10-18.

Reilly, Eithne (2012). An Empirical Investigation of Teachers' Self-Efficacy, SelfEsteem and Job Stress as predictors of job satisfaction. International Journal of Educational Management, 28(4), 234-241.

Ryan, R. M., \& Deci, E. L. (2000). Self-determination theory and the facilitation of intrinsic motivation, social development, and well-being. American psychologist, 55(1), 68 . 
Okpako, E.: Comparative Investigation of Job Motivation, Perceived Job Stress... ЗБОРНИК РАДОВА • ГОД. 23 • БР. 22 • ДЕЦЕМБАР 2020 • 25-42

Salim, S. S., Nasir, R., Arip, M. A. \& Mustafa, M. B. (2012). The Role of Emotional Intelligence on Job Satisfaction among School Teachers. The Social Sciences, 7(3), $125-129$.

Schmitz, G. S. \& Schwarzer, R. (2002). Individuelle und kollektive Selbstwirksamkeitserwartung von Lehrern [Individual and collective self-efficacy of teachers]. Zeitschrift für Pädagogik, 44. Beiheft: Selbstwirksamkeit und Motivationsprozesse in Bildungsinstitutionen, 192-214.

Schwarzer, R. \& Greenglass, E. (1999). Teacher burnout from a social-cognitive perspective: A theoretical position paper. In R. Vandenberghe \& M. Hubermann (eds.), Understanding and preventing teacher burnout: A sourcebook of international research and practice (238-246). Cambridge: Cambridge University Press.

Skaalvik, E. M. \& Skaalvik, S. (2007). Dimensions of teacher self-efficacy and relations with strain factors, perceived collective teacher efficacy, and teacher burnout. Journal of Educational Psychology, 99, 611-625.

Woolfolk, A. E. \& Hoy, W. K. (1990). Prospective teachers' sense of efficacy and beliefs about control. Journal of Educational Psychology, 82, 81-91. 
Okpako, E.: Comparative Investigation of Job Motivation, Perceived Job Stress... ЗБОРНИК РАДОВА • ГОД. 23 • БР. 22 • ДЕЦЕМБАР 2020 • 25-42

\section{Ернест О. Окпако}

Универзитет у Ибадану, Нигерија

\section{КОМПАРАТИВНО ИСПИТИВАЊЕ ПОСЛОВНЕ МОТИВАЦИЈЕ, ОПАЖЕНОГ СТРЕСА У ВЕЗИ ПОСЛА И ПОСЛОВНЕ САТИСФАКЦИЈЕ НА УСПЕШНОСТ НАСТАВНИКА МЕБУ НАСТАВНИЦИМА СРЕДЫИХ ЈАВНИХ И ПРИВАТНИХ ШКОЛА У ДРЖАВИ ЕКИТИ, НИГЕРИЈА}

\section{Резиме}

Ова студија испитује компаративно истраживање пословне мотивације, опаженог стреса у вези посла и пословне сатисфакције на успешност наставника међу наставницима јавних и приватних средњих школа у Држави Екити, у Нигерији. У студији је примењен дескриптивни приступ корелативног типа. Узорак од двеста педесет наставника средњих јавних и приватних школа изабран је користећи технику узорковања на више нивоа. Четири скале су коришћене да се прикупе информације. Осам питања је постављено и на њих се одговарало у истраживању. Прикупљени подаци су анализирани користећи Т-тест и анализу вишеструке регресије. Резултати показују да постоји значајна разлика у успешности подучавања наставника средњих јавних и приватних школа; $\mathrm{t}(248)=-3,206, \mathrm{p}<0,05$. Постојала је такође и знатна разлика у њиховој пословној мотивацији; $\mathrm{t}(248)=$ $-2,159, \mathrm{p}<0,05$. Значајна разлика је примећена и у опаженом стресу међу овим наставницима; $\mathrm{t}(248)=-3,648, \mathrm{p}<0,05$, а такође и значајна разлика у задовољству послом међу наставницима ових школа; $\mathrm{t}(248)=-2,742, \mathrm{p}>0,05$. Регресивна анализа је открила да је постојао заједнички ефекат независних варијабли (пословна мотивација, опажени стрес и пословна сатисфакција) на ефикасност наставника јавних школа $(\mathrm{R}=0,598, \mathrm{P}<0,05) .34,3 \%$ варирања јављало се када су предикторске променљиве узете заједно. Значај комбинованог доприноса је тестиран на (P < 0,05). Даље, постојао је такође заједнички ефекат независних променљивих (пословна мотивација, опажени стрес и пословна сатисфакција) на ефикасност наставника приватних школа $(\mathrm{R}=0,641, \mathrm{P}<0,05) .39,4 \%$ варирања јављало се када су предикторске променљиве узете заједно. Значај комбинованог доприноса је тестиран на $(\mathrm{P}<0,05)$. На основу резултата истраживања, закључено је да је добробит наставника који су покретач средњег образовања веома битна за њихову ефикасност, нарочито у приватним средњим школама. Такође Владини службеници и акционари у средњем образовању морају обезбедити добробит наставника да би олакшали процес учења и довели до доброг подучавања, само-развоја наставника, ученика и нације у целини.

Кључне речи: ефикасност наставника, пословна мотивација, пословна сатисфакиија, опажени стрес, наставници . 